\title{
Media Tourism and Its Role in Sustaining Scotland's Tourism Industry
}

\author{
Stephanie Garrison * (D) and Claire Wallace \\ School of Social Science, University of Aberdeen, Aberdeen AB24 3FX, UK; claire.wallace@abdn.ac.uk \\ * Correspondence: stephanie.garrison2@abdn.ac.uk
}

\begin{abstract}
Popular media, including films, television, comics, videogames, and books, are an increasingly important aspect of contemporary tourism. This is especially the case in Scotland, where popular culture led to the development of Scotland's tourism industry. In this article, we will describe the phenomenon of media-related tourism in Scotland with respect to three selected case studies within Scotland: First, Glenfinnan Viaduct, made famous by the Harry Potter film series; Second, Doune Castle, used as a set for Monty Python, Game of Thrones and more recently, Outlander; Third, Abbotsford, home of Sir Walter Scott, a classical novelist now celebrating his 250th Birthday Anniversary. In examining these case studies, the article will consider how sustainable media tourism is. This approached is from the lens of media tourism and its impact on rural communities, concerns over local infrastructure, wider understandings of media tourism as a growing sub-sector, and the sustainability of the wider Scottish tourism industry in relation to the coronavirus pandemic.
\end{abstract}

Keywords: cultural tourism; media tourism; popular culture; rural communities; sustainability

check for

updates

Citation: Garrison, S.; Wallace, C. Media Tourism and Its Role in Sustaining Scotland's Tourism Industry. Sustainability 2021, 13, 6305. https://doi.org/10.3390/su13116305

Academic Editor: Bart Neuts

Received: 30 April 2021

Accepted: 29 May 2021

Published: 2 June 2021

Publisher's Note: MDPI stays neutral with regard to jurisdictional claims in published maps and institutional affiliations.

\section{Introduction}

Popular media, such as films, novels, comic books, and television series, has long been an impetus for travel to destinations related to a media text [1]. This is especially the case in Scotland, where the image of Scotland is shaped in people's minds by popular media and has contributed to the development of 'media tourism' [2], a niche sub-set of cultural tourism which involves travels inspired by media texts. Whilst discourse on media tourism is typically approached from the perspective of the media tourist [3], this article approaches media tourism from the angle of visitor attractions and the rural communities surrounding these popular sites. In this article, we will describe the phenomenon of media tourism with respect to three selected case studies within Scotland: the Glenfinnan Viaduct, made famous by the Harry Potter film series; Doune Castle, used as a set for Monty Python, Game of Thrones and more recently, Outlander and Abbotsford, home of Sir Walter Scott, a classical novelist who is considered the father of Scottish tourism. In exploring these case studies, this article illustrates how media tourism is an enduring form of cultural tourism that has evolved with the introduction of new media formats. In drawing on the three case studies, we explore the concept of sustainability in the context of media tourism, as it is one of Scotland's most popular forms of tourism. We examine this phenomenon as it relates to conflicts within rural communities, concerns over local infrastructure, a wider understanding of media tourism as a growing sub-sector, and lastly, considering the sustainability of the wider Scottish tourism industry in relation to the Coronavirus pandemic.

\subsection{Literature Review}

Cultural tourism is a continuously evolving mode of tourism. This was evidenced in 2017 when the World Tourism Organisation (UNWTO) gave cultural tourism a more expansive definition. This updated definition better addressed contemporary cultural tourism incorporating, among other things, literature, music, and creative industries 
into the new operational definition [4]. Media, such as music, literature, and film, was recognised as a niche, albeit important, part of cultural tourism. Whilst more recently recognised by the UNWTO, a large corpus of literature has emerged since the 1990s which investigates the phenomenon of media-inspired or popular culture-inspired cultural tourism. The discourse surrounding this phenomenon has categorised media-inspired cultural tourism into various hyper-niche categories, such as literary [5], film-induced [6], cinematic [7], and screen tourism [8]. A wide range of media-inspired tourism has examined this niche form of cultural tourism in a variety of ways, including concerns over overtourism or under-tourism [3], media use in destination market strategies [9], the role of media in place-making and interpretation of place [10], reconstituting geopolitical imaginaries [11] and visitor integration into tourist destinations [12]. Other literature explores the experience and perspective of the visitor in relation to the authenticity of experience and place [4], fan travel as a pilgrimage [13] and the use of imagination in visiting places $[6,7,10]$.

Whilst there continues to be a wide range of literature pertaining to media-inspired tourism, it has been readily acknowledged that media-inspired tourism continues to be studied in isolation and places more emphasis on the mode of media transmission (e.g., film, novel, television series), rather than the content of the media [2,4,12,14]. This is particularly the case with film tourism studies, as film, television, and literary adaptions on screen tend to be clumped into the study of film tourism $[2,4,6,8,12,14]$. However, such hyper-niche categorises, such as film tourism, fail to account for the multi-media nature of modern popular culture consumption. In other words, a novel series (e.g., the Harry Potter novels by J.K. Rowling) can be adapted into a film or television series (e.g., the Harry Potter films), and tourism inspired by these media texts is inspired by the world of Harry Potter, rather than the mode of transmission [12,14-16]. In an effort to move away from hyper-niche forms of media-inspired tourism, scholars have introduced concepts such as 'contents tourism', first introduced in Japan [12] and 'media tourism', first introduced in Europe $[2,14]$. This newer literature advocates for a 'cross-fertilisation' of discourse which de-emphasises the media format and instead examines the contents of popular culture [12] In building on the works of John Caughey and Pierre Nora, Stijn Reijnders developed the concept of 'media tourism' as 'the phenomenon of people travelling to places which they associate with novels, films or television series' [15] (p. 672). Whilst novels, films and television are the primary media explored, the concept of media tourism has expanded to include other popular medias such as music and videogames [3,14,16-19].

Although it has been established that media tourism is a form of cultural tourism, there remain gaps in the examination of popular culture media and cultural tourism. Scholars have noted that the links between popular culture, tourism, and the impact of this type of tourism on communities receives limited attention in English language scholarship [12]. This is particularly the case for rural areas. Whilst it is well established that cultural tourism literature highlights the importance of relationships with both the community and the environment, it does not generally address rural areas. Several case studies have been produced which link media tourism to rural areas, such as parts of New Zealand or the west Highlands of Scotland [20], or more urban areas, such as Dubrovnik, Croatia [21]. However, there is a lack of in-depth qualitative studies which pull together insights from the local communities themselves, from resident to business owner, to visitors and local stakeholders. Where the literature typically points to the standard associated concerns with tourism, such as over-tourism and lack of infrastructure at specific locations related to media tourism (e.g., Doune Castle in Stirlingshire, Scotland), the community and their interests are often side-lined.

\subsection{The Context: Scotland's Tourism Industry and Popular Culture}

Whilst media texts, such as Outlander, Braveheart, Harry Potter, The Da Vinci Code, Monty Python and the Holy Grail, and James Bond, have more recently helped to inspire fans to visit Scotland, the role of popular culture in shaping Scotland's tourism industry reaches as far 
back as the 18th century during the Romantic Movement which swept through Europe and took hold in Scotland. From the mid-to-late 18th century, Scotland had carved out a rudimentary, albeit growing, tourism industry [22] which was inspired by the popular culture of the day. Typically referred to as 'literary tourism', this early form of popular culture inspired tourism concerned travels linked to famed authors, such as Walter Scott, Robert Burns and James Macpherson [22-26], and was inspired by the popular culture of the day, such as literature, poetry, music and art. These popular culture mediums reflected Scotland, particularly the Highlands of Scotland, as steeped in mystery and a place in which urbanites could escape everyday life. The 19th-century works of the novelist, poet, playwright, and historian Sir Walter Scott were particularly influential with his works Lady of the Lake (1810), Waverly (1814), Rob Roy (1817) and The Bride of Lammermoor (1819) being adapted into different media formats, including plays, operas and, later, film.

Scott's works celebrated Jacobitism, two movements in the 17th and 18th centuries, which sought to remove the English king from power and restore the Scottish crown to the Stuart line of kings. The final rising failed in April 1746 with the Battle of Culloden and resulted in the disbanding of the clan system with the Highland Clearance, banning of the kilt and Gaelic language, and transportation of Jacobite supporters to penal colonies. Despite heavily romanticising the Jacobite cause and taking liberties with historical events, Scott's works were immensely popular within the United Kingdom, Europe, and the United States [22]. As a result, the Scottish Highlands saw an influx of visitors seeking out the settings of Scott's stories which interwove the Highlands with heroism, romance, adventure and served as the backdrop to the noble end of the Jacobite cause $[25,27,28]$. This was evidenced in the summer of 1810 when Loch Katrine, the setting of Scott's poem The Lady of the Lake, was inundated with approximately 500 carriages as fans sought a connection with Scott's fictionalized story of King James V and the banished Douglas family [29]. A new hotel was also built in Callendar, near Loch Katrine, in order to cater to the Scott fans visiting the area. The popularity of Scott's stories endured into the 20th century with the North British Railway offering Scott-themed rail holidays in 1907, which would take passengers from England to Scotland to visit Scott's home in Abbotsford, as well as his place of burial and other Scott related landmarks. Scott's association with the cultivation of a sustained tourism industry in Scotland led to the novelist being hailed as the 'father of contemporary tourism' [30]. The early popularity of Scott's works illustrates that contemporary media tourism is rooted in older forms of popular culture-inspired travels in Scotland.

The link between popular culture and tourism to Scotland continued well into the 20th century where new media formats were introduced, encouraging new forms of popular culture to emerge. In the context of Scottish tourism, the advent of film, and later television led to new media texts, such as Whisky Galore! (1949), The Thirty-Nine Steps (1959), Local Hero (1983) and later, Braveheart (1995) and Outlander (2014); however, it also led to adaptations of media texts first introduced in the romanticism era, such as Rob Roy [28]. Whilst academically contentious, the dominant association of Scotland in terms of popular culture and imagination continued to be tethered to 'tartanry' images of the Highlands as mysterious, with misty lochs, heather-covered mountainsides, dashing and honourable Highlanders and a history rich with sorrow, oppression, and loss [24,31-38]. This image was transmitted through a variety of media formats, primarily through Scottishthemed romance novels [39], historical war epics [37] and historical fantasy television programmes [40]. Whilst the tartarised version of Scotland proved to be the most popular inspiration for popular culture tourism, other genres of popular culture have contributed to Scotland's tourism sector, as indicated in case studies on the 2006 thriller film The Da Vinci Code [41], the animated Disney-Pixar film Brave [42] and the costume comedy Monty Python and the Holy Grail [43].

Whilst it is evident that popular culture has informed the development of Scotland's tourism industry since the days of Sir Walter Scott, it was not until the mid-1990s that media tourism was actively promoted by official tourism bodies [41,44]. The push to 
promote Scotland's media links became apparent with the 1995 release of the Hollywood war epic Braveheart. The film was based on the events of the Scottish Wars of Independence and engendered a significant tourism boom in Scotland, with Scotland being branded as 'Braveheart Country' by destination market organisations (DMOs) [41]. This campaign led by the Scottish Tourism Board (now VisitScotland), along with the popularity of the film, contributed to the number of visitors to Scotland increasing by $4 \%$ in 1995 , with a 1996 survey showing that 1 in 5 visitors from the USA was influenced by seeing Scotland on screen [45]. The same year, nearly $£ 15$ million worth of tourist revenue was injected into the economy. This socio-economic impact on the tourism sectors was then labelled the 'Braveheart-effect' as it was tourism generated from the film.

This appeal has carried on into the 21st century, and in terms of motivational appeal, a 2015-2016 VisitScotland survey indicated that 1 in 10 visitors was influenced to visit Scotland based on exposure to books, television programmes or films about Scotland [30]. Rather than Braveheart being the motivator for visits, instead the new popular media text is the novel and television series Outlander. The ongoing book series was created in 1991 by American author Diana Gabaldon. With Scotland and Scottish history and heritage central to the plot, the Outlander series is the story of Claire Randall, an English World War II figure, who, after touching a set of standing stones, travels two hundred years into the past and finds herself in 18th Scotland on the cusp of the Jacobite Risings. There Claire finds herself beholden to the Clan Mackenzie and is forced to marry, and eventually falls in love with, the chief Mackenzie's nephew, Jamie. With Claire's future knowledge of the failure of the Jacobites, Claire and Jamie attempt, but ultimately fail, to prevent the Battle of Culloden from occurring. In 2014 the production company, Sony Productions, developed Outlander into a high-end television series filmed almost exclusively in Scotland. Currently into its fifth season, Outlander has been met with immense success, and not only has the show help to regenerate Scotland's creative economy but has also led to a significant tourism surge for which Diana Gabaldon was formally recognized by VisitScotland for her contributions to Scottish tourism $[30,46,47]$.

\section{Material and Methods}

The methodology was based upon case studies [48] and drew upon empirical inquiry. This involved identifying and selecting cases that can be compared. It can involve persons, schools, institutions, events and so on and is, therefore, a very flexible mode of inquiry. Whilst a flexible mode of inquiry, the cases must be defined by a set of criteria in order to ground the study (Table 1). As such, three case studies were selected which meet the following criteria. First, the chosen case study sites were associated with different media texts. Second, they were located within rural areas in Scotland. Third, they were tourist destinations as a result of their association with these texts, even if the associations were based upon imaginary narratives [3]. A further factor was that each of these case study sites were owned and managed by different organisations, with each organisation representing key institutions in Scottish heritage: an independent charitable foundation (The Abbottsford Trust), Scotland's lead heritage and conservation public body Historic Environment Scotland (Doune Castle) and the Scottish conservation organisation the National Trust for Scotland (Glenfinnan).

The advantage of the case study method is that it involves the collection and assemblage of information and data for a specifically defined site. As relevant data can be wide-ranging, this method enables the triangulation of information from across each case study and between cases which can be both qualitative and quantitative, hence improving the reliability of both $[49,50]$. In this case, the following data collection methods were used: geographical information about the site, site visits and observations, qualitative online interviews, collation of pre-coronavirus (COVID-19) era policy documents and COVID-19 era policy documents and analysing public newspaper reporting on the impact of COVID-19 on the tourism and hospitality industry. 
Table 1. Criteria for the case study.

\begin{tabular}{|c|c|c|c|}
\hline Site & Abbotsford & Doune Castle & Glenfinnan Viaduct \\
\hline Rural & Yes & Yes & Yes \\
\hline Local population & $14,632(2015)$ & $2150(2016)$ & $120(2011)$ \\
\hline $\begin{array}{l}\text { Media associated } \\
\text { with site }\end{array}$ & $\begin{array}{l}\text { Sir Walter Scott } \\
\text { literature }\end{array}$ & $\begin{array}{l}\text { Sir Walter Scott, } \\
\text { Monty Python and the } \\
\text { Holy Grail, Game of } \\
\text { Thrones, Outlander, } \\
\text { Outlaw King, Mary } \\
\text { Queen of Scots }\end{array}$ & $\begin{array}{l}\text { Sir Walter Scott, Harry } \\
\text { Potter, Jacobite } \\
\text { uprisings }\end{array}$ \\
\hline Owner/manager & Abbotsford Trust & $\begin{array}{l}\text { Historic Environment } \\
\text { Scotland }\end{array}$ & $\begin{array}{l}\text { National Trust for } \\
\text { Scotland }\end{array}$ \\
\hline $\begin{array}{l}\text { No. of Tourist } \\
\text { visitors } 2019\end{array}$ & $80-100,000$ est. & 152,987 & 462,235 \\
\hline $\begin{array}{l}\text { No. of Tourist } \\
\text { visitors } 2020\end{array}$ & 47,000 est. & 30,000 & 200,000 est. \\
\hline Visitor facilities & $\begin{array}{l}\text { Café, restaurant, } \\
\text { shop, toilets and } \\
\text { visitor centre }\end{array}$ & Toilets, shop & $\begin{array}{l}\text { Visitor centre with } \\
\text { exhibition, toilets, } \\
\text { café and restaurant }\end{array}$ \\
\hline
\end{tabular}

The geographical information connected to each site was entered into a database for the entire project. The interviews took place between December 2020 and February 2021 and were conducted online due to national COVID-19 restrictions. These interviews were with the managers of each of the sites as well as with 12 vloggers, bloggers and tour operators associated with the sites. The site visits and observation undertaken were used to select the sites and involved eliminating sites that were in various ways not suitable. The collection of pre-COVID-19 policy documents focused on policy related to Scottish tourism from 2019 and included data such as visitor numbers and planned policy framework. The collection of COVID-19 era policy documents is yet to be analysed. The next phase of the research is to carry out a survey with tourists, businesses, and residents, but this has had to be delayed due to COVID-19 restrictions. In addition, analysis of newspapers was carried out to track events as the COVID-19 pandemic unfolded.

Yin [51] identifies three types of case studies. The Exploratory Case Study is used to identify hypotheses and questions, the Descriptive Case Study is used to describe a particular phenomenon within its context and the Explanatory Case Study is used to establish cause and effects. Our media tourism case studies fell between the Exploratory and the Descriptive since they have been used to develop questionnaires that will be fielded in 2021. The aim of this paper is to lay out the descriptive parameters that have been used for purposes of comparison between case studies and in order to lay the foundations for the next stage of analysis.

\section{Results}

Media tourism, particularly in rural areas, has not been identified nor systematically explored in Scotland despite being a place where media tourism has had a clear emergence and continues to thrive. The Aberdeen SPOT case study addresses this by extending beyond a singular investigation of media tourism and its economic impact on a national scale. Instead, our project directs focus to people and rural areas affected by media tourism, such as travel content creators (bloggers and vloggers), tour operators and local business owners and residents. We also investigate the relationship between media, Scotland and those who visit Scotland as 'fans' of either Scotland, as a place, or Scotland as presented in a larger fictive narrative (e.g., in Harry Potter or Outlander). Our case study also examines the impact of Covid-19 on rural communities, which typically experience high volumes of media tourists each year considering the outbreak of Coronavirus. 
In order to investigate media tourism in Scotland and its impact on rural communities, three case studies were chosen, which were linked to either novels, films, or television programmes. These case studies were Abbotsford in the Scottish Borders, Doune Castle in Stirlingshire, and the Glenfinnan Viaduct in the Scottish Highlands. These sites were chosen for case studies as they represent three different examples of media tourism in Scotland from 19th- to 21st-century popular culture. The first site of investigation was Abbotsford. Abbotsford is the historic baronial mansion and estate that was home to Sir Walter Scott (Figure 1).

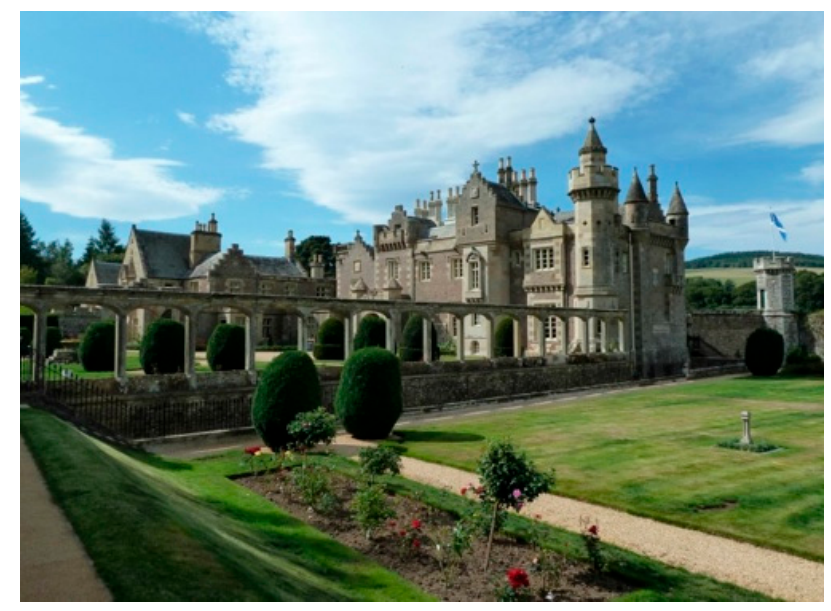

Figure 1. Abbotsford. Copyright: The Abbotsford Trust. Used with permission.

As noted earlier, Scott inspired an image of Scotland that captivated the minds of his readers and earned the novelist the title of father of Scottish tourism. Abbotsford illustrates this connection as it is the home where Scott penned some of his most famous works. Since 1833 , the house has welcomed visitors and provided an excellent link to some of the earliest modes of media tourism in Scotland. The house was particularly popular in the 1970s; however, its popularity waned. In 2011 Abbotsford underwent a substantial two-year refurbishment and with funding from a private individual, as well as the Heritage Lottery Fund, Historic Environment Scotland, and Borders Council. The house re-opened in 2013 and in 2019, received approximately 80-100,000 visitors. The refurbishment included an updated café/visitor centre with an exhibition of the life of Sir Walter Scott and self-guided tours through the house. The SPOT project focuses on previously unexplored links to rural development in the area. For example, rural infrastructural development has aided in bringing more visitors to Abbotsford as the installation of a new Borders Railway in 2015 attributed to a $12 \%$ rise in visitor numbers the following year. Additionally, there is an exploration of the role that popular culture plays in encouraging visits to the area.

Doune Castle is a 15th-century medieval castle located in Stirlingshire, Scotland (Figure 2). Where Abbotsford provides a cultural link to the literary medium of popular culture, this site represents the convergence of several different modes of media tourism and illustrates the ephemeral nature of media texts and tourism.

The castle has been a pilgrimage site for media fans since the 19th century due to Scott's novel Waverly (1814). Part of the story involves a young Englishman named Edward Waverly being captured by Jacobites and held in Doune Castle. Whilst tourism to Doune was limited during Scott's lifetime, Waverly does illustrate one of the first references of the castle in popular media and imagination. The relationship between media tourism and Doune Castle has become only more apparent within the last 45 years as media tourists have made up a significant portion of visitors to Doune Castle since the mid-1970s thanks to Monty Python and the Holy Grail (1975). As noted by Beeton [6], a third of the visits to Doune Castle were Monty Python fans as the castle featured in the film as the fictional Castle of Guy de Lombard, Swamp Castle, Camelot and Castle Anthrax. This connection 
was promoted by the Historic Environment Scotland by hosting a Monty Python day at Doune Castle and offering an audio tour guide by Monty Python actor, Terry Jones. Whilst the Monty Python day no longer runs, more recently, Doune Castle has experienced yet another cycle of media tourism with the historical film Outlaw King (2018), and as Winterfell, the stronghold of the Stark family, in the pilot episode of Game of Thrones. By far the most significant media text to link popular culture to Doune Castle is the television series Outlander [46-48]. Doune Castle features as Castle Leoch, the fictional ancestral seat of the Clan Mackenzie in the television series. Since it has featured in season 1 of the television series Outlander as the Castle Leoch, Doune Castle has attracted fans of the time-travelling historical fantasy drama. According to the Association of Scottish Visitor Attractions (ASVA), this has resulted in an influx of tourism to the castle and the surrounding area, with numbers increasing from 68,517 in 2014 to 152,987 in 2019, a significant $226.5 \%$ increase $[30,45,46,52,53]$.

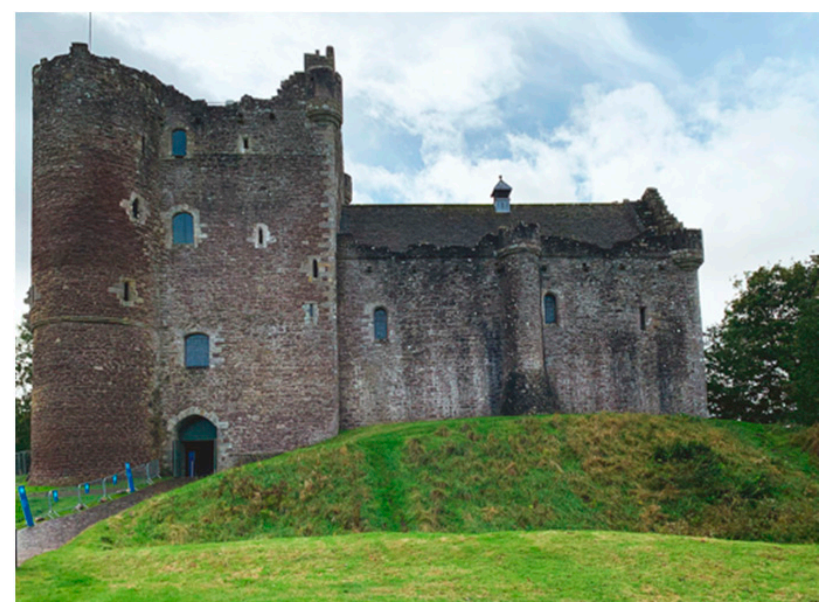

Figure 2. Doune Castle exterior. Author's own.

The Glenfinnan Viaduct is located in the Highlands of Scotland (Figure 3). Since its appearance in the Harry Potter film series transporting witches and wizards aboard the Hogwarts Express steam train to Hogwarts School of Witchcraft and Wizardry, the Glenfinnan Viaduct has become a pilgrimage destination for fans of the Harry Potter novels by J.K. Rowling and the subsequent films. Additionally, Loch Shiel, which features in several other Harry Potter films is located across the road.

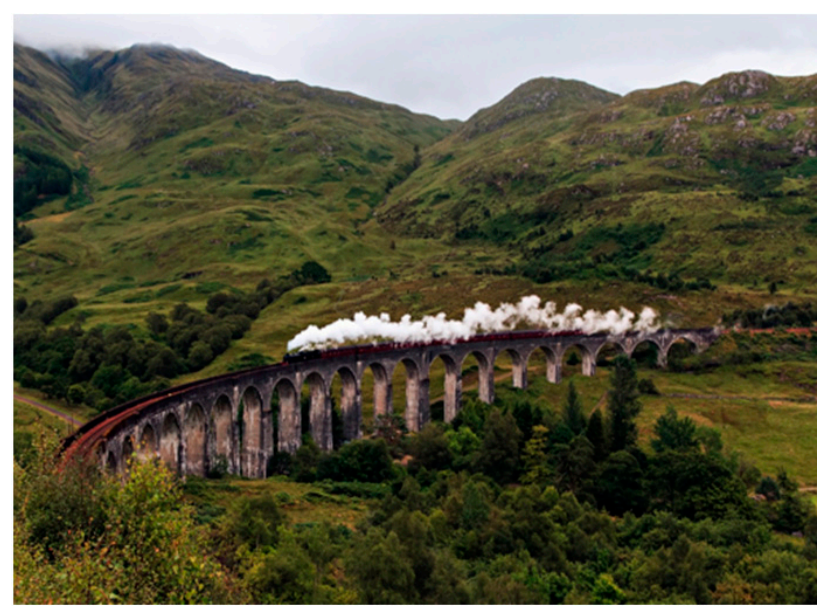

Figure 3. Glenfinnan Viaduct. Copyright: Simone A. Bertinotti CC by 2.0. 
Visits to the viaduct continue to climb, with visits doubling in a five-year period from 200,000 visitors in 2014, to just over 460,000 visitors in 2019 [52,53]. These numbers are largely associated with tourism related to popular culture. Fans of Harry Potter climb up the lookout point in order to see the Jacobite steam train cross the bridge, much like Harry does on board the Hogwarts Express en route to Hogwarts [54]. More recently, this site has also attracted fans of Outlander as Glenfinnan was also where Charles Stuart raised his standard in August 1745. Whilst the site is not featured in the Outlander novels or television programme, a major storyline of the series deals with the events and consequences of Charles Stuart's Jacobite cause.

\section{Discussion}

Whilst three case studies are chosen to investigate the link between popular culture and tourism in Scotland, there is recognition of larger issues that manifest beyond this niche type of tourism. As highlighted with Loch Katrine and Walter Scott's early forms of media tourism in Scotland, issues of infrastructure concerns are as old as Scottish tourism and do not present new challenges. What does become challenging is that, more broadly, over the past thirty years, there has been a notable rise in mass media tourism, spurred by the reduction in transportation costs, increased access to media with the development of social media platforms, streaming services, eBooks and the internet and the mainstreaming and legitimising of popular culture [2,55-59]. As a result, the volume of visitors has increased and poses fresh concerns. This is particularly the case in rural areas where locations are inundated with media tourists at a level where it is unsustainable. Infrastructural issues have been raised at two of the three case studies due to the high volumes of tourists in a relatively short period. At Glenfinnan Viaduct and Doune Castle, car parking poses a particular challenge as there are not enough car parking spaces to meet the demand of visitors. In Glenfinnan, this has been a going concern that is being addressed by local authorities and the National Trust for Scotland, the caretakers of the Glenfinnan Viaduct and Visitor Centre with the installation of a new car park. Doune Castle's management of parking has been more limited in the application for a temporary overflow parking permit with the local council.

Another issue involves the relationship, or lack thereof, between local rural communities and visitors. In an extension of car parking concerns, the caretakers of the castle and grounds, Historic Environment Scotland (HES), have faced issues of being limited in the number of vehicles that can safely access the car park. Additionally, the site is only accessible by car or coach bus with limited access to the village, much to the irritation of the businesses within the village of Doune. Whilst challenging, there is evidence of community engagement through the presence of media tourism in Doune. For example, HES regularly engages with the local community. Local residents have free access to the castle grounds and have worked with HES to mitigate concerns over foot traffic. More recently, the collaborative efforts of the local community and HES resulted in the installation of a footpath leading from the village of Doune up to the castle. This allows easier walking methods to the castle and offers visitors the opportunity to access the businesses, such as cafes, restaurants and shops, which are located in the village. Whilst Abbotsford does not face the challenges of car parking to the extent that Doune or Glenfinnan does, it still faces challenges in that there is limited access to the site. There is only one bus that goes to Abbotsford and one train line for the Borders area. Abbotsford has tried to mitigate this challenge by offering a shuttle van service that collects visitors from the train station in Galashiels.

A further point of investigating sustainable methods of engaging with media tourism is to re-examine the role of the visitor in relation to their identity as visitor, as a fan and their relationship to a site. Whilst there is scholarship that explores the visitor's relationship to a real-life place related to a particular media [2,58,60-63], there is a lack of discourse surrounding fan engagement at local levels [3]. As such, the role of fans must be considered within the context of shaping media tourism. For example, we should be looking at 
how fan bases work to develop regional tourism as a means to celebrate a media text or franchise, both with and without collaboration with stakeholders, such as local community enterprises. Some work has already been undertaken in examining the role of the fan as media tourist who created their own media text-based tours [2]. or how fans work closely with local and regional organisations to promote fan bases and encourage respectful tourist etiquette [45] and take on the role of fan activist [63]. This is shown with Garrison's [45] case study of Outlander fans, where fans of the novels and television show created a local map of Inverness complete with tie-in quotes from the Outlander books and television show and references to how local spots link to the Outlander narrative universe. This map was created by fans and supported by the local community through endorsements. This map also represented the collaborative efforts of local community stakeholders rather than the national tourist organisation, VisitScotland. However, more research is needed to understand the interplay between fan identities as tourists and promoters of place.

Additionally, fan-hosted events, which also serve as a tourist boost for a local area, should also be explored. In this regard, consideration should be given to the role that fans, as media tourists and as tourist facilitators, have in stimulating, promoting, and cultivating media tourism. As such, future research investigation is needed to fully develop a cohesive academic discourse on the linkages between fan studies and tourism studies.

In investigating the role of fans in media tourism, another point that must be considered within a sustainable framework is the ephemeral nature of the popularity of media texts and tourism. As noted above, within the last 25 years, Scotland has borne witness to the rise and fall of several media texts which directly impacted Scottish tourism. As illustrated with case studies on The Da Vinci Code [23,64], Braveheart [6,65], Monty Python [6] and Outlander [45,47], popularity of media texts peaks at one point or another. What we must question is, what do these media texts leave behind? What is the legacy of such an impact on rural communities? To understand this, we must first move to understand the phenomenon as well. At present. VisitScotland defines media related tourism as screen tourism and provides the following definition [30] (p. 2):

Known by many names-screen tourism, film tourism, set-jetting or film-induced tourism, it all relates to a visitor's journey. Put simply, screen tourism is a genre of tourism that provides a connection with the location of a film or a TV series. A trip to a set or filming location will take the visitor into the centre of their fandom, where they can experience a new dimension of their favourite TV show or film.

Such a definition fails to encapsulate the full breadth of popular culture's impact, regardless of which media format a media text is presented in. This is evident with the re-telling and re-interpretation of Scott's works, and later, the adaptation of books, such as Outlander and Harry Potter, into globally successful television and films.

A final point to consider is 'black swan' events and the ramifications of such events. This has been the case with the Coronavirus pandemic. This is a topic that needs to be explored by researchers in the future as media tourism is a particular type of tourism that is made possible by the travel, or pilgrimage, to the locations feature in popular media. With the implementation of local, regional and, at one point, national, lockdowns the tourism and hospitality industry were brought to a standstill. Emerging from this development came discussions with stakeholders and bloggers and vloggers on the future of Scottish tourism, and particularly media tourism. Whilst the impact of the COVID-19 pandemic will certainly be felt at all levels of tourism, we must now ask: Can media tourism continue to exist when the locations which bring the visitor closer to the media text are inaccessible? What happens when the media tourist cannot engage in physical media tourist practices, such as touring studios, partaking in bus tours, attending conventions, guided tours or going to theme parks? Will the long-term effects of the Coronavirus see a marked decline in media tourism as a specific form of tourism?

Research should include how, and in what ways, media tourists are turning to other forms of 'travel' as a way to experience media tourism. This was a topic of discussion in the interviews with stakeholders and bloggers and vloggers. For example, it was made evident 
that as a by-product of the COVID-19 lockdown and the stay-at-home orders preventing physical travel, there has been the growth of 'virtual tours' being offered by tour operators, bloggers and DMOs. With the rise in digital connectivity, virtual experiences have become commonplace in the form of linking into live 'walk with me' tours or pre-recorded YouTube videos [66]. In the context of Scottish tourism, virtual tours are being used as part of a 'top of mind' tourism strategy which promotes adherence to government-mandated travel restrictions whilst encouraging future visits. Content producers such as bloggers and vloggers have also turned to virtual tourism as a means to keep their travel blogs relevant and popular. Tour operators have introduced virtual tours ranging from pre-recorded tours to live 'walk with me' tours which have been experienced by individuals wanting to 'travel' and by corporations for employees [66,67]. Additionally, there is a divide between whether or not businesses offer these virtual tours free or at cost. Whilst such modes of 'travel' have risen in popularity during the pandemic and have created an impetus towards virtual tourism, there lacks a proper business model for this type of tourism [67]. As such, future research must look towards developing and exploring sustainable business models for virtual tourism, which will outlive the COVID-19 pandemic.

\section{Conclusions}

This article explored how popular culture helped shape Scotland's contemporary tourism industry. In drawing on three selected case studies, Abbotsford, Doune Castle, and the Glenfinnan Viaduct, it was illustrated how popular culture has inspired tourism to Scotland from the 19th century through to the 21st century. In focusing on these case studies, it was shown how media tourism is threaded through different case studies and media formats. We followed the position of Reijnders [3] and Beeton [5] in seeing media tourism as an important aspect of cultural tourism more generally, but that the "culture" in question often refers to popular culture, which is ephemeral in nature in that it can wax and wane quickly following media trends. Nevertheless, an important thread related to the romanticisation of the Highlands that was begun by Sir Walter Scott 200 years ago and connects the case studies that we have chosen. The case studies exemplify aspects of rural and media tourism to enable fruitful comparison.

The article then turned to engaging with the question of how sustainable this type of tourism is. Although placemaking and geographical identity is an important aspect of this popular construction of the site, media tourism, if not well managed, can alienate the residents who might be confronted with a large and unexpected influx of tourists due to the sudden popularity of a media text. We have described some of the management methods undertaken by the site owners to engage with local communities to overcome the problems of over-tourism and ways in which fans can become a community asset if they are also enrolled in the development of cultural tourism sites. This was addressed by exploring older issues such as congestion in rural areas, conflict with rural communities and how this might be addressed. Additionally, sustainability was also addressed by bringing into question the ephemeral nature of media texts, the usefulness of 'screen tourism' as a term and calling for more sustainable engagement with fans who go beyond the role of visitor to support sustainable tourism in rural areas. The article concluded a final point of exploration in relation to the wider Scottish tourism industry as it recovers from the Coronavirus pandemic.

Author Contributions: Conceptualization, S.G. and C.W.; methodology, S.G. and C.W.; investigation, S.G. and C.W.; resources, S.G. and C.W.; data curation, S.G.; writing-original draft preparation, S.G.; writing - review and editing, S.G. and C.W.; supervision, C.W.; project administration, S.G. and C.W.; funding acquisition, S.G. and C.W. All authors have read and agreed to the published version of the manuscript.

Funding: This research is undertaken as part of the SPOT Horizon 2020 project funded by the EU under grant agreement 870644. SPOT: Social and Cultural Innovation Platform on Cultural Tourism and its Potential Towards Deepening Europeanisation. www.spotprojecth2020.eu (accessed on 1 June 2021). 
Institutional Review Board Statement: The study was conducted according to the guidelines of the Declaration of Helsinki, and approved by the Ethics Committee of the University of Aberdeen (11 November 2020).

Informed Consent Statement: Informed consent was obtained from all subjects involved in the study. Data Availability Statement: Not applicable.

Conflicts of Interest: The authors declare no conflict of interest.

\section{References}

1. Lee, C. 'Have Magic, Will Travel': Tourism and Harry Potter's United (Magical) Kingdom. Tour. Stud. 2012, 12, 52-69. [CrossRef]

2. Reijnders, S. Places of the Imagination: Media, Tourism, Culture; Ashgate: Farnham, UK, 2011.

3. Phillipov, M. Media Tourism and Rural Romance: Constructing Food Television's 'Cult Geographies'. In Media and Food Industries; Phillipov, M., Ed.; Springer International Publishing: Berlin/Heidelberg, Germany, 2017; pp. 107-131. [CrossRef]

4. Richards, G. Cultural tourism: A review of recent research and trends. J. Hosp. Tour. Manag. 2018, 36, 12-21. [CrossRef]

5. Squire, S.J. The cultural values of literary tourism. Ann. Tour. Res. 1994, 21, 103-120. [CrossRef]

6. Beeton, S. Travel, Tourism, and the Moving Image; Channel View Publications: Bristol, UK, 2015.

7. Tzanelli, R. Constructing the 'cinematic tourist': The 'sign industry' of The Lord of the Rings. Tour. Stud. 2004, 4, 21-42. [CrossRef]

8. Buchmann, A.; Moore, K.; Fisher, D. Experiencing Film Induced Tourism. Ann. Tour. Res. 2010, 37, 229-248. [CrossRef]

9. Lundberg, C.; Lindström, K.N. Sustainable Management of Popular Culture Tourism Destinations: A Critical Evaluation of the Twilight Saga Servicescapes. Sustainability 2020, 12, 5177. [CrossRef]

10. Chen, H.; Zuo, Y.; Law, R.; Zhang, M. Improving the Tourist's Perception of the Tourist Destinations Image: An Analysis of Chinese Kung Fu Film and Television. Sustainability 2021, 13, 3875. [CrossRef]

11. Mostafanezhad, M.; Promburom, T. 'Lost in Thailand': The popular geopolitics of film- induced tourism in northern Thailand. Soc. Cult. Geogr. 2018, 19, 81-101. [CrossRef]

12. Seaton, P.; Yamamura, T. Japanese Popular Culture and Contents Tourism Introduction. Jpn. Forum 2015, 27, 1-11. [CrossRef]

13. Couldry, N. Pilgrimage in Mediaspace: Continuities and Transformations. Etnofoor 2007, 20, 63-73.

14. Norris, C. Creating Godzilla's Media Tourism. Available online: http://refractory.unimelb.edu.au/2012/11/06/norris/ (accessed on 1 June 2021).

15. Reijnders, S. Stories that move: Fiction, imagination, tourism. Eur. J. Cult. Stud. 2016, 19, 672-689. [CrossRef]

16. Graburn, N.; Yamamura, T. Contents tourism: Background, context, and future. J. Tour. Cult. Chang. 2020, 18, 1-11. [CrossRef]

17. Lamerichs, N. Hunters, climbers, flâneurs. In The Routledge Handbook of Popular Culture and Tourism, 1st ed.; Lundberg, C., Ziakas, V., Eds.; Routledge: London, UK, 2018; pp. 161-169. [CrossRef]

18. Lundberg, C.; Ziakas, V. The Routledge Handbook of Popular Culture and Tourism; Routledge, Taylor \& Francis Group: London, UK, 2019.

19. Williams, R. Funko Hannibal in Florence: Fan Tourism, Participatory Culture, and Paratextual Play. JOMEC J. 2019, 14, 71. [CrossRef]

20. Cloke, P. Creativity and tourism in rural environments. In Tourism, Creativity and Development; Richards, G., Wilson, J., Eds.; Routledge: London, UK, 2007; pp. 37-47.

21. Depken, C.A.; Globan, T.; Kožić, I. Television-Induced Tourism: Evidence from Croatia. Atl. Econ. J. 2020, 48, 253-262. [CrossRef]

22. Durie, A.J. Scottish Tourism: The Long View, 1700-2015; Routledge: London, UK, 2017.

23. Clyde, R. From Rebel to Hero: The Image of the Highlander 1745-1830; Tuckwell Press Ltd.: Glasgow, UK, 1995.

24. Edensor, T. National Identity, Popular Culture and Everyday Life; Berg Publishers: Oxford, UK, 2002.

25. Meng, L. The Mythology of Tourism: The Works of Sir Walter Scott. and the Development of Tourism in Scotland; Peter Lang: Oxford, UK, 2018.

26. Watson, N. Holiday romances: Or, Loch Katrine and the literary tourist. In Literary Tourism, the Trossachs, and Walter Scott; Brown, I., Ed.; Association for Scottish Literary Studies: Glasgow, UK, 2012; pp. 56-69.

27. Grenier, K.H. Tourism and Identity in Scotland, 1770-1914: Creating Caledonia; Ashgate Publishing: Farnham, UK, 2005.

28. Nestor, M.C. Revisiting The Lady of the Lake: Walter Scott and the Representation of Scotland. Scott. Lit. Rev. 2020, 12, 61-80.

29. Leask, N. Stepping Westward: Writing the Highland Tour c. 1720-1830, 1st ed.; Oxford University Press: Oxford, UK, 2020.

30. VisitScotland. The Outlander Effect \& Tourism. VisitScotland. 2019. Available online: https://www.visitscotland.org/binaries/ content/assets/dot-org/pdf/research-papers-2/20190314-outlander-effect-2019.pdf (accessed on 21 March 2021).

31. Butt, R. Looking at Tartan in Film: History, Identity and Spectacle. In From Tartan to Tartanry Scottish Culture, History and Myth; Brown, I., Ed.; Edinburgh University Press: Edinburgh, UK, 2010. [CrossRef]

32. Caughie, J. "Scottish Television: What would it Look Like?" In Scotch Reels: Scotland in Cinema and Television; McArthur, C., Ed.; BFI: London, UK, 1982; pp. 112-122.

33. Hagemann, S. Literary Tartanry As Translation. In From Tartan to Tartanry: Scottish Culture, History and Myth; Brown, I., Ed.; Edinburgh University Press: Edinburgh, UK, 2010; pp. 151-165. 
34. Goldie, D. Don't Take the High Road: Tartanry and its Critics In From Tartan to Tartanry: Scottish Culture, History and Myth; Brown, I., Ed.; Edinburgh University Press: Edinburgh, UK, 2010; pp. 232-245.

35. Hume, I. Tartanry into Tartan: Heritage, Tourism and Material Culture. In From Tartan to Tartanry: Scottish Culture, History and Myth; Brown, I., Ed.; Edinburgh University Press: Edinburgh, UK, 2010; pp. 82-91.

36. James, A. Enchanted places, land and sea, wilderness: Scottish highland landscape and identity in cinema. In Representing the Rural: Space, Place, and Identity in Films about the Land; Fowler, C., Helfield, G., Eds.; Wayne State University Press: Detroit, MI, USA, 2006; pp. 185-201.

37. McArthur, C. Brigadoon, Braveheart, and the Scots: Distortions of Scotland in Hollywood cinema. I.B. Tauris: London, UK, 2003.

38. Riach, A. Tartanry and its discontents: The idea of popular Scottishness. In From Tartan to Tartanry: Scottish Culture, History and Myth; Brown, I., Ed.; Edinburgh University Press: Edinburgh, UK, 2010; pp. 115-128.

39. Hague, E. Mass Market Romance Fiction and the Representation of Scotland in the United States. In The Modern Scottish Diaspora: Contemporary Debates and Perspectives; Leith, M.S., Sim, D., Eds.; Edinburgh University Press: Edinburgh, UK, 2014; pp. 171-190.

40. Topler, J.; Špenko, T. Film tourism as a tool of tourism development: The Representation of Scotland in the Outlander TV series. TIMS 2019, 13, 79-88. [CrossRef]

41. Martin-Jones, D. Film tourism as heritage tourism: Scotland, diaspora and The Da Vinci Code (2006). New Rev. Film Telev. Stud. 2014, 12, 156-177. [CrossRef]

42. Tzanelli, R. Heritage entropy and tourist pilgrimage in Brave's Scotland. Hosp. Soc. 2014, 4, 155-177. [CrossRef]

43. Edensor, T. Tourism. In International Encyclopedia of Human Geography; Elsevier: Amsterdam, The Netherlands, 2009; pp. 301-312. [CrossRef]

44. Olsberg SPI. Stately Attraction: How Film and Television Programmes Promote Tourism in the UK; Olsberg and SPI Publications: London, UK, 2007.

45. Garrison, S. Beyond fandom: Outlander Facebook fan groups and the guardianship of an imagined Scotland. J. Fandom Stud. 2020, 8, 83-101. [CrossRef]

46. Cateridge, J. "What if your future was the past?" Time Travel, Genealogy and Scottish Television Tourism in Outlander (2014-). Int. J. Scott. Theatre Screen 2018, 11, 67-83.

47. McGucken, S. 'A love letter to Scotland:' The Creation \& Conception of Heritage. In Adoring Outlander: Essays on Fandom, Genre and the Female Audience; Frankel, V.E., Ed.; McFarland \& Company: Jefferson, NC, USA, 2016; pp. 7-22.

48. Yin, R.K. Case Study Research: Design and Methods, 3rd ed.; Sage Publications: New York, NY, USA, 2003.

49. Cresswell, J.W.; Gutterman, T. Educational Research: Planning, Conduction and Evaluating Qualitative and Quantitative Research, 6th ed.; Pearson: Harlow, UK, 2020.

50. Risjord, M.; Dunbar, S.B.; Moloney, M.F. A new foundation for methodological triangulation. J. Nurs. Scholarsh. 2002, 34, 269-275. [CrossRef]

51. Yin, R.K. Mixed methods research: Are the methods genuinely intergrated or merely parallel? Res. Sch. 2006, 13, $42-47$.

52. Association of Scottish Visitor Attractions. 2014 ASVA Annual Visitor Trend Report. ASVA. 2021. Available online: https: / / asva.co.uk/app/uploads/2021/02/Annual-Report-VT-report-2014.pdf (accessed on 21 March 2021).

53. Association of Scottish Visitor Attractions. 2019 ASVA Annual Visitor Trend Report. ASVA. 2021. Available online: https: / / asva.co.uk/app/uploads/2021/02/ASVA-Annual-Visitor-Trends-Report-2019.pdf (accessed on 21 March 2021).

54. Lunastorta, S. Glenfinnan Viaduct [photograph]. Flickr. 2014. Available online: https://www.flickr.com/photos/36632182@N07/ 14878122082CCby2.0 (accessed on 21 March 2021).

55. Couldry, N. The Place of Media Power: Pilgrims and Witnesses of the Media Age; Routledge: London, UK, 2000.

56. Jenkins, H. Convergence Culture: Where Old and New Media Collide; New York University Press: New York, NY, USA, 2006.

57. Sandvoss, C. Fans: The Mirror of Consumption; Polity Press: Cambridge, UK, 2005.

58. Waysdorf, A.; Reijnders, S. The role of imagination in the film tourist experience: The case of Game of Thrones. Particip. J. Audience Recept. Stud. 2017, 14, 170-191.

59. Williams, R. Media tourism, culinary cultures, and embodied fan experience: Visiting Hannibal's Florence. In The Routledge Companion to Media and Tourism, 1st ed.; Månsson, M., Buchmann, A., Cassinger, C., Eskilsson, L., Eds.; Routledge: London, UK, 2020; pp. 277-286.

60. Hovi, T. Dracula Tourism as Pilgrimage. Pilgrimages Today. AAbo: Donner Institute for Research in Religious and Cultural History. Scr. Inst. Donneriani Abo. 2010, 22, 211-227. [CrossRef]

61. Light, D. The truth of the crowds: Social media and the heritage experience. In The Cultural Moment in Tourism; Smith, L., Waterton, E., Watson, S., Eds.; Routledge, Taylor \& Francis Group: London, UK, 2012; pp. 59-78.

62. Lundberg, C.; Lexhagen, M. Pop Culture Tourism: A Research Model. In Fan Studies: Researching Popular Audiences; InterDisciplinary Press: Oxford, UK, 2014; pp. 12-34.

63. Jenkins, H.; Shresthova, S. Up, up, and away! The power and potential of fan activism. Transform. Works Cult. 2012, 10. [CrossRef]

64. Månsson, M. Mediatized tourism. Ann. Tour. Res. 2011, 38, 1634-1652. [CrossRef]

65. Edensor, T. Performing tourism, staging tourism: (Re)producing tourist space and practice. Tour. Stud. 2001, 1, 59-81. [CrossRef] 
66. Jarratt, D. Webcam-travel: Conceptual foundations. Annals of Tourism Research, 103088. 2020. Available online: https: / / doi.org/10.1016/j.annals.2020.103088 (accessed on 29 December 2020).

67. Ioannides, D.; Gyimóthy, S. The COVID-19 crisis as an opportunity for escaping the unsustainable global tourism path. Tour. Geogr. 2020, 22, 624-632. [CrossRef] 